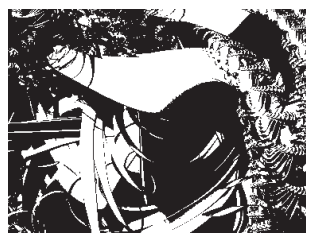

\title{
DIMENSIONS OF NATIONAL INNOVATION CULTURE IN CROATIA Content Validity of Hofstede's Dimensions
}

Jasminka LAŽNJAK

Faculty of Humanities and Social Sciences, Zagreb

UDK: 316.42(497.5):001

008(497.5)

Izvorni znanstveni rad

Primljeno: 8. 4. 2011.

Faced with the challenge to increase the level of innovation in science and technology many societies have developed a national innovation system as a form of public policy programs. If innovative culture is crucial for the adoption and development of new technologies, it is of great importance to explore the concept and possibly find out which type of culture is more innovative than others. Presented in the paper are the results of the first empirical study of innovation culture in Croatia based on a survey on the representative sample of Croatian population. Drawing on Hofstede's concept of dimensions of national culture, Croatian national innovation culture is operationalized as a set of value orientations and norms (uncertainty avoidance, individualism, masculinity - femininity, long-term or short-term orientation, and power distance). Four scales based on Hofstede's dimensions were constructed, which mainly support the content validity of his concept. They could be used to measure differences in innovative capacity between groups and regions. The analysis shows the presence of multiple dimensions of innovation culture in Croatia that might hinder innovation capacity, but this doesn't necessary lead to the conclusion that we can identify one type culture elements as the only model for strengthening the innovative culture.

Keywords: national innovation culture, dimensions of national culture, Hofstede, Croatia

$\triangle \quad$ Jasminka Lažnjak, University of Zagreb, Faculty of Humanities and Social Sciences, Department of Sociology, I. Lučića 3, 10000 Zagreb, Croatia. E-mail: jlaznjak@ffzg.hr 
Development of knowledge economy relies heavily on knowledge application and knowledge use that is conventionally coined in the term of innovation. Starting with the pioneering OECD study (OECD, 1992), innovation and technological development is growingly recognized as a complex social phenomenon which opens the platform for socio-cultural research on innovation.

Since the thesis of knowledge and innovation as the basis for development and prosperity and their embeddedness into the socio-cultural and political environment was widely accepted, it has been an incentive for social studies of science and technology and innovation studies to grow more rapidly. Innovation became the issue very high on the agenda in various disciplines such as economy, sociology, business management, policy and cultural studies. The different rate of national innovativeness and dynamics in innovation production leads to the conclusion that the process of innovation as well as national innovation capacities are embedded in socio-cultural and political processes and therefore both are contextual, path dependent and locally specific (Mytelka and Smith, 2002; Furman et al., 2002).

The concept of national innovation policy (Lundvall, 2007) has emerged in a form of public policy programs that would foster innovation by capitalization of science through productive use of national scientific and technological potentials. National innovation systems emphasized the crucial role of socio-economic actors to create an innovation conductive institutional environment. Apart from institutions which directly and deliberately promote the acquisition and dissemination of knowledge such as R\&D departments, technological institutes and universities (Freeman, 2002), some other important factors from the political and cultural environment shape the scale, direction and relative success of all innovative activities (Rammert, 2002). Therefore, innovations have become endogenous and evolving, conditioned by the social and institutional context (Furman et al., 2002; Pavitt, 1998). Societies in the developed and developing world faced the challenge to increase the level of innovation in science and technology. For innovation policy makers in many countries the problem emerged regarding how to adapt existing good practices and create efficient policy measures for their own country. The questions are: why are some societies more innovative than others, and do existing cultural conditions determine when, how and in what form innovation will be adopted? The fact that the same formal structure, organization, technology or types of econo- 
my don't function equally in different countries or societies has directed innovation studies to look for the answers in social institutions and culture.

\section{THE CONCEPT OF NATIONAL CULTURE AND INNOVATION CULTURE}

Traditional discourses on technology development rooted in technological determinism led to a technocratic type of technology policy that mostly relied on the universal criteria of efficiency and success. National innovation systems were tuned according to the best practice of the leaders in technological development (Rammert, 2002). The social shaping of technology (MacKenzie and Wajcman, 1999) and social construction of technology (Bijker et al., 1989) are widely accepted perspectives in STS (science, technology and society) research. Although both approaches emphasised the influence of non-technical factors in the choice between alternatives of technology development, they haven't broadened that perspective to a cultural and institutional one (Rammert, 2002).

In order to measure the cultural influences on innovation capacity, it is necessary to define the conception of culture which will be able to capture the important aspects regarding innovative activities. Culture is defined in social sciences as a set of shared values, norms and expected behaviours. It is the pattern of arrangement or behaviour adopted by the society or the group as an accepted way of solving problems; it is a "blueprint for life" (Kluckhohn, 1951). Social relations (important for the preservation of society) are kept in the institutions as relatively permanent social arrangements. Culture includes all the institutionalized ways and all the implicit beliefs, norms and values. Institutions (informal, long-lasting clusters of norms, values and beliefs reproduced by socialization) and social and human capital are the important parts of culture that might be supportive or hindering for innovation.

Some authors (Wieland, 2006; Rammert, 2002) have found C. Geertz' (Geertz, 1973) definition of culture as the most appropriate to apply in the innovation culture concept. Culture is defined as a group's or society's frame that determines how things are viewed differently and done differently and how activities are institutionally arranged. Defined in this way, culture is always local, historical and context dependent (Wieland, 2006). This also means that culture is a kind of abstract and formalised concept of economy and politics and not opposed to them (Rammert, 2002). On the other hand, Hofstede argues for a more definite and less flexible conception of culture. He defines culture as "collective programming of the mind which distinguishes the members of one group or category of people from another" (Hofstede, 1994, 5). He argues that people 
DRUŠ. ISTRAŽ. ZAGREB GOD. 20 (2011) BR. 4 (114),

STR. 1015-1038

LAŽNJAK, J. DIMENSIONS OF.. belong to different culture groups at the same time (like nation, gender, and organisation), but national culture is of particular importance regarding economy. National culture as a set of beliefs and values distinguishes one nationality from the other and it is extremely stable. This stability is the result of the institutionalisation of dominant cultural value systems which reinforce culture patterns (Hofstede, 2001).

His concept of national culture consists of six dimensions (Hofstede, 2010). ${ }^{1}$

1) Power distance (PDI) is the extent to which the less powerful members of organizations and institutions (like the family) accept and expect unequally distributed power (it means inequality from below).

2) Uncertainty avoidance (UAI) deals with a society's tolerance for uncertainty and ambiguity. It indicates to what extent a culture programs its members to feel either uncomfortable or comfortable in unstructured situations.

3) Individualism versus collectivism (IDV/COL) is the degree to which individuals are integrated into groups (individualism means that everyone is expected to look after her/himself and collectivism refers to societies where people are integrated into strong, cohesive in-groups protecting them in exchange for unquestioning loyalty).

4) Masculinity versus femininity (MAS/FEM) refers to the distribution of emotional roles between the genders.

5) Long-versus short-term orientation (LTO/STO): Long-term oriented societies foster pragmatic virtues oriented towards future rewards, in particular saving, persistence, and adapting to changing circumstances. Short-term oriented societies foster virtues related to the past and present such as national pride, respect for tradition, preservation of "face", and fulfilling social obligations.

6) Indulgence versus restraint (IN/RES): Indulgence stands for a society that allows relatively free gratification of basic and natural human drives related to enjoying life and having fun. Restraint stands for a society that suppresses gratification of needs and regulates it by means of strict social norms.

Acknowledging that innovative culture is crucial for the adoption and development of new technologies, a new research area has emerged with empirical studies based on the concepts of national culture and social capital. The concept of innovation culture incorporates informal institutions and values as important factors in the shaping of innovation and has thus broadened the national innovation systems' approach. 
DRUŠ. ISTRAŽ. ZAGREB GOD. 20 (2011), BR. $4(114)$ STR. 1015-1038

LAŽNJAK, J.: DIMENSIONS OF...
Innovation has many definitions, most of them referring to J. Schumpeter: "The introduction of new goods (...), new methods of production (...), the opening of new markets (...), the conquest of new sources of supply (...) and the carrying out of a new organization of any industry" (Schumpeter, 1934; OECD, 1997). Here innovation is explored as a part of every culture in the sense that innovation is built in the collective memory of the solutions that society developed to deal with its problems (Schein, 1984).

Innovation culture can be studied on three levels:

1) On the level of organization, innovation culture refers to formal organization (set of explicit norms and rules) on the one hand, and on the other, to organizational climate and organizational culture (informal groups, relations, values, etc.). Corporate innovation culture is a very common concept in organizational studies (Ahmed, 1998). Innovative organization requires a culture which nurtures innovation and is conducive to creativity. The reductionist approach simply identifies innovation with higher R\&D expenditure. But the definition of innovation also includes problem-solving; the ability to see a need and think creatively how that need might be met in a better way. Characteristics of a highly innovative organization are: awareness, intense motivation, a surfeit of skills and competence and supportive infrastructure. Innovation is enhanced by organic (flexible, non-hierarchical, informal, participative) structures rather than mechanic, rigid, bureaucratic, hierarchical) structures and increased by use of highly participative structures and cultures (Khazanchi et al., 2007).

2) On the individual level, personality traits for innovation are: experience, broad interests, attraction to complexity, high energy, independence of judgment, intuition, self-confidence, ability to accommodate opposites, firm sense of self as creative, curiosity, and intellectual honesty.

3) On the macro level, the concept of innovation culture relates to the values, norms and social capital on the levels of societies and country/national cultures. This level of innovation culture is touched upon by various authors but most of them referred to the most known cultural anthropologist Geert Hofstede, although he has not explicitly analysed innovation culture (Didero et al., 2008; Jucevičius, 2007).

Innovation culture is usually understood in terms of institutions (norms, values, formal and informal institutions) which significantly influence how actors involved in the process of innovation perceive economic and technical challenges and how it provides the strategies to cope with them (Wieland, 2006). It implies norms and values like attitudes toward innovation, technology, entrepreneurial activities, business, un- 
DRUŠ. ISTRAŽ. ZAGREB GOD. 20 (2011) BR. 4 (114),

STR. 1015-1038

LAŽNJAK, J.: DIMENSIONS OF..

(1) TABLE 1

Research on the impact of cultura dimensions on innovation certainty avoidance, individualism, long-term or short-term orientation, and power distance (Hofstede, 2001; Didero et al., 2008).

During the past decade it has been greatly discussed how some types of culture are more supportive for innovation and "learning economy" (Lundvall, 2007) than others, referring to mostly dimensions of culture defined by Hofstede (1994) and Herbig (1994). There is an impressive literature discussing, approving and criticizing Hofstede's concept of national culture ${ }^{2}$ (Kirkman et al., 2006). Our intention is not to join the discussion of the appropriateness of the term or the entire concept of national culture and if these dimensions really reflect national culture. National culture, if something like this exists, consists of many other characteristics and elements apart from Hofstede's dimensions (McSweenney, 2002; Taras et al., 2009). However, accepting all the criticism of the concept of national culture, we cannot completely disregard the findings that some of these dimensions are correlated to the innovation capacity of countries, groups of countries or regions. Several studies have demonstrated the influence of culture on innovation using Hofstede's dimensions of national culture (See Table 1). The differences in cultural dimensions and other cultural values and their impact on innovation have been tested for various dependent variables such as rates of innovation, number of patents, patents application, innovation implementation and innovation performance (Franke et al., 1991; Shane, 1993; Van Everdingen and Waarts, 2003; Williams and McGuire, 2005; Kaasa and Vadi, 2008; Vecchi and Brennan, 2009).

\begin{tabular}{|c|c|c|c|}
\hline Authors & Sample & Innovation variables & Impact of cultural dimensions \\
\hline Shane (1993) & 33 countries & No of trademarks per capita & PDI - IDV + MAS 0 UAI - \\
\hline $\begin{array}{l}\text { Williams, Mc- } \\
\text { Guire (2005) }\end{array}$ & 63 countries & $\begin{array}{l}\text { Economic creativity } \\
\text { Innovation implementation }\end{array}$ & $\begin{array}{l}\text { PDI } 0 \text { IDV + MAS } 0 \text { UAI } 0 \\
\text { PDI - IDV + MAS } 0 \text { UAI - }\end{array}$ \\
\hline Willems (2007) & 43 countries & $\begin{array}{l}\text { Patent applications } \\
\text { R\&D expenses }\end{array}$ & PDI - IDV + MAS + UAI - LTO+ \\
\hline $\begin{array}{l}\text { Vecchi, Brennan } \\
\text { (2009) }\end{array}$ & 24 countries & $\begin{array}{l}\text { Innovation inputs } \\
\text { Innovation process } \\
\text { Innovation performance }\end{array}$ & $\begin{array}{l}\text { PDI+ IDV-MAS- UAI - } \\
\text { PDI+ IDV-MAS- UAI } 0 \\
\text { PDI+ IDV-MAS } 0 \text { UAI } 0\end{array}$ \\
\hline $\begin{array}{l}\text { Kaasa, Vadi } \\
\text { (2008) }\end{array}$ & 20 countries & Patent applications & $\begin{array}{l}\text { PDI - IDV0 MAS- UAI - } \\
\text { Family related collectivism - }\end{array}$ \\
\hline
\end{tabular}

In the previous studies large power distance has been found 
DRUŠ. ISTRAŽ. ZAGREB GOD. 20 (2011), BR. 4 (114) STR. 1015-1038

LAŽNJAK, J.: DIMENSIONS OF... tralized authority and more trust between different hierarchical levels.

Higher innovation capacity has been commonly related to more individualistic cultures because that type of society implies autonomy, independence and freedom - values which regard higher inventive and useful ideas and have a positive effect on economic creativity. Both recent studies confirmed a positive relationship between individualism and innovation rate (Willems, 2007; Kaasa and Vadi, 2008). The effect of masculinity/femininity dimension on innovation hasn't been unanimously proved in previous researches. While Shane (1993) and Williams and McGuire (2005) demonstrated no effect of masculinity on innovation, later studies showed different results: Willems' (2007) study determined a positive correlation between masculinity and innovation but Kaasa and Vadi (2008) confirmed the hypothesis of negative relationship between masculinity and innovation initiation.

Although uncertainty avoidance is often emphasised as the important dimension in negative relation with innovation, empirical studies have not unanimously confirmed that hypothesis. The negative impact of uncertainty avoidance on innovation is proven in the following studies: Shane (1993), Williams and McGuire (2005) and Kaasa and Vadi (2008) while researches by Van Everdongen and Waarts (2003) and Vecchi and Brennan (2009) haven't verified that assumption. No empirical evidence has yet supported the influence of long/short term orientation on innovation except in Willems (2007), probably because this dimension was added in later Hofstede surveys and has not been included in previous studies regarding effects on innovation.

Despite much justified criticism of Hofstede's model, its wide use in different areas challenged us to further explore the applicability of these dimensions on the concept of innovation culture (McSweeney, 2002; Williamson, 2002). So far, it still remains to be proven if Hofstede's cultural dimensions are "valid as an explanatory construct for innovation performance" (Vecchi and Brennan, 2009). Nevertheless, Hofstede's model is regarded as the most extensive research of cross-national values, the number of countries included in his study was larger than any other, and the reliability of the dimensions has been repeatedly tested.

Some authors hold that existing cultural conditions determine when, how and in what form innovation will be adopted. In a culture where behaviour, ideas, attitudes and "technological base" that are congruent with innovation are already present - the chances of adopting innovation are higher (Herbig and Dunphy, 1998). Higher innovation capacity, accord- 
DRUŠ. ISTRAŽ. ZAGREB GOD. 20 (2011)

BR. 4 (114),

STR. 1015-1038

LAŽNJAK, J.:

DIMENSIONS OF.. ing to several international comparative surveys, is associated with societies characterized by higher individualism, willingness to take risks, readiness to accept change, long-term orientation, low power distance, weak uncertainty avoidance, openness to new information, value of education to society, positive attitudes toward science, religion, and early adopters. Innovators are early adopters but it is not the other way round, early adopters are not necessarily innovators (Didero et al., 2008).

The empirical researches on the impact of cultural dimensions on innovation show that using Hofstede's model could be a useful concept in studying the influence of cultural values on various aspects of innovation. They also prove that innovation is a multidimensional concept that cannot be grasped in simple indicators.

\section{EXPLORING DIMENSIONS OF THE INNOVATION CULTURE IN CROATIA}

So far there has been little empirical research of innovation culture in Croatia. One focused on the micro level of organisational innovation culture examined the content of the differences in innovative culture in various European countries among which was Croatia. The analysis revealed statistically significant differences in innovation culture dimensions between Western and Eastern countries (Sušanj, 2000). The analysis of socio-cultural and political aspects of the Croatian innovation system on a macro level investigated the influence of social capital operationalized as values, value orientations and trust in institutions on the Croatian national innovation system (Švarc et al., 2009). Even though the Croatian government has made a significant effort, especially since 2001, to develop the Croatian innovation system and innovation policy, their influence on innovativeness of companies in a broad sense and, commercial exploitation of scientific research in a narrow sense, is rather modest or even non-existing. The main findings indicated that a significant part of the scientific community (within engineering and technology) is strongly oriented towards innovation based on commercialisation of research results and prefer the entrepreneurial type of universities more than traditional university. However, the other features of social capital of the research community (statism, paternalism, traditionalism) combined with the lack of companies' interest for innovation make the innovation system weak and inefficient. The overall lack of innovation capacities of companies and their interest for cooperation with the scientific sector make the innovation policy programs, in part, also inefficient (Švarc et al., 2011). 


\section{Croatian low innovation performance}

Innovation is commonly linked to the factors of economic growth such as GDP per capita, R\&D expenditure or number of patents (Franke et al., 1991; Willems, 2007). For EU countries, analyses indicated that countries in northern Europe show a higher innovation rate correlated to higher GDP while in south Europe there is a lower innovation rate linked with lower GDP (Hasan and Tucci, 2010; Global Innovation Index, 2011).

Croatian economy, although leading in the region, suffers from slow growth and weak competiveness while technological capabilities are falling back rather than catching up with the EU countries (Moore and Vamvakidis, 2007). The lack of structural changes in economy towards new innovation-based companies or knowledge based sectors combined with the low innovation index (European Innovation Scoreboard 2008) provide a platform for a thesis that Croatia failed to capitalise inherited scientific potentials in order to accelerate transition to knowledge economy (Švarc, 2008). The Croatian government has made a significant effort, especially since 2001, to develop the Croatian innovation system and innovation policy, but ac-

(1) TABLE 2 cording to the European innovation scoreboard 2008, Croatia

Development in innovation is in one of the catching-up countries and slow growers with performance in $\mathrm{EU}^{*}$ a rate of improvement below that of the EU27 (see Table 1).

\begin{tabular}{|c|c|c|c|c|}
\hline Group & Growth rate & Growth leaders & Moderate growers & Slow growers \\
\hline Innovation leaders & $1.5 \%$ & Switzerland & Finland, Germany & $\begin{array}{l}\text { Denmark, Sweden, } \\
\text { United Kingdom }\end{array}$ \\
\hline Innovation followers & $2.7 \%$ & Cyprus, Estonia & Iceland, Slovenia & $\begin{array}{l}\text { Austria, Belgium, } \\
\text { France, Ireland, } \\
\text { Luxembourg, } \\
\text { Netherlands }\end{array}$ \\
\hline Moderate innovators & $3.3 \%$ & $\begin{array}{l}\text { Czech Republic, } \\
\text { Greece, Malta, } \\
\text { Portugal }\end{array}$ & $\begin{array}{l}\text { Hungary, Lithuania, } \\
\text { Poland, Slovakia }\end{array}$ & $\begin{array}{l}\text { Italy, Norway, } \\
\text { Spain }\end{array}$ \\
\hline Catching-up countries & $5.5 \%$ & Bulgaria, Romania & Latvia, Turkey & Croatia \\
\hline
\end{tabular}

Average annual growth rates as calculated over a five-year period.

*Table 2 is adopted from European Innovation Scoreboard report (EIS) 2009, p. 14.

Table 2 shows the development in the innovation performance for EU members and Innovation index from EIS (European Innovation Scoreboard). EIS is a composite index which includes multiple indicators in the following dimensions: human resources, finance and support, firm investments, linkages and entrepreneurship, patents and other throughputs, innovators and economic effects. The average annual growth rate in innovation performance is calculated over a five year 
DRUŠ. ISTRAŽ. ZAGREB GOD. 20 (2011) BR. 4 (114),

STR. 1015-1038

LAŽNJAK, J.: DIMENSIONS OF.. period (EIS, 2009, p. 49). Based on their innovation performance, the countries in this report were divided in four groups: Innovation leaders with innovation performance above the EU27 average, Innovation followers with innovation performance close or above that of EU27 average but below leaders, Moderate innovators with innovation performance bellow EU27 average and catching-up countries with innovation performance well below the EU27 average. The term "catching-up" is widely used in policy studies and usually regards a broader range of areas in which less developed transition Member States try to reach the benchmarks set by more developed Member States (Veugelers and Mrak, 2009).

The data indicate that Croatia is falling behind not only by low patenting rate or low R\&D expenditure but also in many other indicators. The lack of structural changes and institutional deficit as the explanation of the inefficient function of Croatian national innovation system has been in the earlier studies connected to the deficit of social capital (Švarc et al., 2009). The concept of innovative culture includes social capital as well but offers a broader view of the possible impact of value orientations on the innovation performance of the country.

As previously mentioned several studies confirmed the correlation between some dimensions of national culture and innovation (Shane, 1993; Williams and McGuire, 2005; Vecchi and Brennan, 2008; Minkov and Blagoev, 2009; Van Everdingen and Waarts, 2003). The impact of national culture on innovation capacity/adoption is empirically confirmed, with respective differences among studies. Innovation is positively correlated to: higher individualism, weak uncertainty avoidance, long term orientation, lower power distance. Some other studies confirmed the impact of culture on innovation by measuring different indicators (Didero et al., 2008) where higher innovation capacity in societies is characterized by: positive attitude toward science, value of education to society, frequent travel, early adopters (innovators are early adopters but not the other way round), and religion (in some cases strict segregation of church and public affairs is considered to be beneficial toward innovation, while in Islamic countries and Hinduism and Buddhism, religion is regarded as a hindering factor for innovation capacity).

We have tested the possible relationship between dimensions of national culture and innovation performance in the European context by using original Hofstede's scores for six dimensions of national culture (Hofstede, 2010) and scores of composite innovation index from the European Innovation Scoreboard 2009 (EIS, 2010) 3 for 33 European countries. European Innovation Scoreboard (EIS) provides comparative assessments of the innovation performance based on 29 indicators of seven dimensions grouped into three main blocks: 1. Enablers 
DRUŠ. ISTRAŽ. ZAGREB GOD. 20 (2011) BR. $4(114)$ STR. 1015-1038

LAŽNJAK, J.: DIMENSIONS OF...

\section{RESEARCH AIM}

- the main drivers of innovation external to the firm (human resources and finance and support), 2. Firm activities (firm investments, linkages and entrepreneurship and throughputs IPR, and 3. Outputs (innovators and economic effect).

Hofstede's scores for dimensions of national culture are adopted from published data on the author's website (http://www. geerthofstede.nl/research--vsm/dimension-data-matrix.aspx).

A Spearman's Rank Order correlation was run to determine the relationship between scores of dimensions of national culture (power distance, individuality, masculinity, uncertainty avoidance, long term vs. short term orientation, and indulgence vs. restraint) and composite innovation index scores for EU27 countries plus Croatia, Iceland, FYR Macedonia, Norway, Switzerland and Turkey. There was a strong, positive correlation between dimensions of indulgence vs. restraint and individuality with innovation score $\left(\mathrm{r}_{\mathrm{s}}(\mathrm{ivr})=0.722, \mathrm{p}=0.000\right.$; $\left.\mathrm{rs}_{\mathrm{s}}(\mathrm{idv})=0.446 ; \mathrm{p}=0.014\right)$. Significant negative correlation was found between dimensions of power distance and uncertainty avoidance and innovation score $\left(\mathrm{r}_{\mathrm{s}}(\mathrm{pdi})=-0.666, \mathrm{p}=0.000\right.$; $\mathrm{rs}($ uai $)=0.442 ; p=0.015$ ). Dimensions of masculinity vs. femininity and long term vs. short term orientations are not significantly correlated to innovation score (See Appendix 1). The results indicate that countries with higher innovation performance are characterized by a smaller power distance and uncertainty avoidance accompanied with a higher individuality and inclination toward indulgence more than restraint.

The purpose of the research is to explore the set of values i.e. value orientations that form a type of innovation culture in Croatia using dimensions of national culture as the basis for conceptualization of innovation culture dimensions.

The concept of innovation culture is operationalized as a set of value orientations and norms which served as indicators for dimensions of uncertainty avoidance, individualism, masculinity - femininity, long-term or short-term orientation, and power distance. Drawing on Hofstede's $(2001,2004)$ dimensions of national cultures and their application on innovation culture, the Croatian survey uses different indicators of the concept of innovation culture. In this way, our research operates as a content validity check for Hofstede's dimensions. Content validity refers to the degree to which a measure covers the range of meanings included within a concept (Babbie, 2008). It is an attempt to assess the degree to which the conceptualization accurately translated the construct into the operationalization and hence the choice of the concept's name. In this case the conceptualisation of national culture started from Hofstede's dimensions, but in operationalization new items are 
DRUŠ. ISTRAŽ. ZAGREB GOD. 20 (2011), BR. 4 (114),

STR. 1015-1038

LAŽNJAK, J.:

DIMENSIONS OF..

\section{SAMPLE}

\section{CONSTRUCTION OF SCALES OF NATIONAL INNOVATION CULTURE}

Exploratory factor analysis with Principal component analysis and Varimax rotation was used to obtain the national culture dimensions scales. Varimax rotation was chosen to avoid the correlated factors as was the case in some previous studies using confirmative factor analysis (Kaasa and Vadi, 2008). Since the main aim of the study was to perform the content validity check of Hofstede's concept of national culture, we tried to get uncorrelated factors representing separate dimensions of culture.

The initial 24 items were analysed. Four extracted factors have significant loadings on 16 items with $49,66 \%$ of total variance explained (See Appendix 2). These factors served to construct 4 scales of national culture dimensions. We used Cronbach's Alpha to test the reliability of our scales and dropped 1 item in Masculinity scale and 1 item in Individualism/collectivism scale to increase Alpha.

The statements indicating values associated with national culture dimensions were measured by a standard Likert scale where 1 means strongly disagree; 2 - disagree; 3 - cannot decide; 4- agree; 5- strongly agree. We have not used Hofstede's Values survey module questionnaire and consequently not his indexing and scores.

In the research we did not include the last dimension of Hofstede's model, Indulgence vs. restraint due to limitations in the construction of the questionnaire but also because this last 
DRUŠ. ISTRAŽ. ZAGREB GOD. 20 (2011), BR. 4 (114)

STR. 1015-1038

LAŽNJAK, J.:

DIMENSIONS OF.. dimension was not analyzed in context of innovation culture in previous research and its influence on innovation is yet to be explored. Here are presented Hofstede's conceptualization of dimensions of national culture along with a list of selected differences between societies that are associated with each dimension and validated by research (Hofstede, 2010). They are followed by our conceptualization presented as scales with mean values and Cronbach's Alpha coefficient indicating consistency of each scale.

\section{Weak and strong uncertainty avoidance}

Hofstede defines uncertainty avoidance "as the extent to which the members of institutions and organizations within a society feel threatened by uncertain, unknown, ambiguous, or unstructured situations." (Hofstede, VSM08 Manual)

List of selection of differences between societies includes: Uncertainty inherent in life is felt as a continuous threat that must be fought; intolerance of deviant persons and ideas; need for clarity and structure; staying in job even if disliked. (State-

(1) TABLE 3

Uncertainty

avoidance scale ment is statistical.)

\begin{tabular}{lrc}
\hline & Mean & Std. Deviation \\
\hline The first task of the state is to secure order & 4.15 & 1.086 \\
Care for the family should be the basic task for every state & 4.05 & 1.147 \\
To achieve social justice should be the basic task of our state & 4.15 & 1.034 \\
Scale mean & 4.113 & \\
Cronbach's Alpha & 0.686 & \\
\end{tabular}

Uncertainty avoidance dimension was the first extracted factor with $13.35 \%$ of variance explained. All three statements included in our scale indicate strong uncertainty avoidance. The respondents have positively agreed with all items suggesting that the Croatian population prefers security and certainty in life over unknown, uncertain and unstructured situations (Table 3).

\section{Masculinity - femininity scale}

Hofstede's dimension of masculinity "stands for a society in which social gender roles are clearly distinct: men are supposed to be assertive, tough, and focused on material success; women are supposed to be more modest, tender, and concerned with the quality of life. Femininity stands for a society in which social gender roles overlap: both men and women are supposed to be modest, tender, and concerned with the quality of life." (Hofstede, VSM08 Manual) 
Hofstede's list of selection of differences between societies includes: Maximum/minimum emotional and social role; balance between family and work; fathers deal with facts, mothers with feelings; admiration for the strong; moralistic attitudes about sexuality; differentiation between genders.

\begin{tabular}{lcc}
\hline & Mean & Std. Deviation \\
\hline If in a marriage only one spouse is employed, & & \\
$\quad$ it is more natural that it is a man & 3.11 & 1.488 \\
Women are by nature more suited for housework & 3.22 & 1.364 \\
Men are closer to public activities and women & 2.77 & 1.277 \\
$\quad$ are closer to private activities & 2.63 & 1.452 \\
Raising children is more mother's than father's duty & 2.82 & \\
Scale mean & 0.752 & \\
Cronbach's Alpha & & \\
\end{tabular}

The masculinity - femininity scale consists of statements indicating a strong "masculine" attitude regarding gender roles that are strongly distinct and stress the differentiation between genders. This was the second extracted factor with $12.8 \%$ of variance explained. The level of agreement is negative in two of four items regarding the exclusion of women from public activities and supporting traditional gender roles in raising children. The respondents very moderately supported the traditional division of labour between genders. The research confirmed the Croatian move toward a moderate feminine type of society (Table 4).

\section{Power distance}

Hofstede explains the dimension of power distance as "...the extent to which the less powerful members of institutions and organizations within a society expect and accept that power is distributed unequally" and represents inequality defined from below (Hofstede, VSM08 Manual). The list of differences between national societies associated with power distance validated by previous research includes among others the following:

The use of power should be legitimate, or power is a basic fact of society, its legitimacy is irrelevant; parents teach children obedience or treat children as equals, subordinates expect to be told what to do or to be consulted; income distribution is very uneven or rather even; hierarchy means existential inequality, corruption is frequent (rare).

Our scale includes three statements examining the level of agreement/approval of large power distance: teaching children obedience, the use of power is legitimate, obedience is understood as virtue. The power distance dimension was the third extracted factor with $11.7 \%$ of variance explained. Item means refer a relatively large power distance (Table 5). 
(1) TABLE 5

Power distance scale

\begin{tabular}{lcc}
\hline & Mean & Std. Deviation \\
\hline There are two kinds of people in the world, strong and weak & 3.24 & 1.378 \\
The most important thing for children is to & 3.55 & 1.274 \\
$\quad$ teach them obedience to parents & 3.52 & 1.215 \\
A key to good life is obedience, discipline and virtues & 3.437 & \\
Scale mean & 0.720 & \\
Cronbach's Alpha & &
\end{tabular}

\section{Individualism vs. collectivism}

For Hofstede "Individualism is the opposite of Collectivism. Individualism stands for a society in which the ties between individuals are loose: a person is expected to look after himself or herself and his or her immediate family only. Collectivism stands for a society in which people from birth onwards are integrated into strong, cohesive in-groups, which continue to protect them throughout their lifetime in exchange for unquestioning loyalty." (Hofstede, VSM08 Manual)

List of selection of differences between societies includes: "We" consciousness vs. "I" consciousness; stress on belonging;

(1) TABLE 6

Individualism collectivism scale harmony should always be maintained; opinions and votes predetermined by in-group; others classified as in group or out-group.

\begin{tabular}{lrc}
\hline & Mean & Std. Deviation \\
\hline The history of our people must be sacred for all of us & 3.82 & 1.228 \\
The common origin of our nation is the basis for our trust & 3.54 & 1.195 \\
By fighting for our state we as people have fought for our dignity & 3.66 & 1.260 \\
Scale mean & 3.457 & \\
Cronbach's Alpha & 0.740 & \\
& & \\
\hline
\end{tabular}

The Individualism - collectivism scale was the fourth factor with $11.2 \%$ of variance explained. The statements included in our scale indicate collectivistic values that stress "we" consciousness, loyalty to your own group, importance of belonging to family and nation. All three items with positive mean suggest the prevalence of collectivistic values (Table 6).

\section{Long term orientation - short term orientation scale}

Long term orientation according to Hofstede "stands for a society which fosters virtues oriented towards future rewards, in particular adaptation, perseverance and thrift. Short term orientation stands for a society which fosters virtues related to 
DRUŠ. ISTRAŽ. ZAGREB GOD. 20 (2011)

BR. 4 (114),

STR. 1015-1038

LAŽNJAK, J:

DIMENSIONS OF.. the past and present, in particular respect for tradition, preservation of "face", and fulfilling social obligations." (Hofstede, VSM08 Manual)

List of selection of differences between societies includes: A universal guideline about what is good and evil; traditions are sacrosanct; family life guided by imperatives; children should learn to be thrifty; most important events in life occurred in the past/ in the future.

The statements in the survey which were indicators of Long/short term orientation had either low factor loadings or were equally loaded on two factors. Two of the items loaded on the Individuality - Collectivism factor. This dimension is the only that hasn't been proved by the content validity test. The explanation might be that dimensions of culture are not independent but correlated, which has been indicated in some previous similar research like in Kaasa and Vadi (2008).

In the literature presented earlier in the text, innovation is fostered by a heterogeneous, open and flexible environment, which translated to dimensions of national culture means that innovation might be stimulated by culture characterized by individualism, masculinity and weak power distance. Spearman's correlation test of original scores and Hofstede's dimensions of national culture with scores of innovation performance (see Appendix 1 ) might support the argument that countries with smaller power distance and uncertainty avoidance accompanied with higher individuality and leaning more toward indulgence than restraint, are countries with higher innovation performance.

The constructed scales of national culture indicate that Croatian dimensions of culture are characterized by large power distance, strong uncertainty avoidance and collectivism with a tendency toward a more feminine society. The dimension of long/short term orientation has not been confirmed by factor analysis.

\section{CONCLUSION: ARE DIMENSIONS OF CROATIAN CULTURE SUPPORTIVE FOR INNOVATION?}

The aim of our research was to perform the content validity check of Hofstede's dimensions of national culture and use these dimensions to construct the scales that may be used to measure differences in dimensions among Croatian regions or among other groups and explore the possible influence of culture dimensions on innovation.

In our research, we have explored norms and values associated with innovation culture using Hofstede's dimensions of national culture as a basis for the conceptualization of national innovation culture. They were operationalized as a set 
DRUŠ. ISTRAŽ. ZAGREB GOD. 20 (2011), BR. $4(114)$ STR. 1015-1038

LAŽNJAK, J.: DIMENSIONS OF... of value orientations and norms measured by different instruments. The constructed scales confirmed content validity of four out of five Hofstede's dimensions leaving out Long/short term orientation. The analysis showed higher scores for power distance, prevailing collectivism and stronger uncertainity avoidance which might be associated with lower innovation capacity.

Croatia as a transitional, post-communist country still has a low innovation capacity and suffers from social capital deficit. It is burdened by traditional values considered to be dysfunctional for innovation, such as statism, collectivism, cooperativeness deficiency, low trust in institutions, state paternalism, and opportunism.

How can we change the state of the art? How to develop institutions (values and norms) that are functional for innovation culture and suppress the dysfunctional? Formal and informal institutions mutually interact in such a way that informal institutions shape formal institutions, they can enable or hinder changes. Formal institutions can help in perseverance of informal ones but they can initiate their change by sanctions. Values determine behaviour through structures (economic, political, and social) in which they are embodied. The creation of new structures should follow the development of new values (Županov, 1995). Nevertheless, culture has multiple elements which may strengthen or hinder innovation tendencies. Values do not exist, they are constructs which serve us to understand and explain human behaviour, and maybe to predict it in some cases. It would be incorrect and potentially dangerous to analyze culture isolated from its context and thus identify one type as the only model for fostering innovation on the level of society or for innovative organization. Shaping the national innovation system according to technology development leaders in Europe or in the world without taking into account the socio-cultural context might hinder the efficient implementation of such programs and produce unintended consequences (Švarc et al., 2011). There is more than one satisfactory combination of cultural elements that leads to innovation successfully. Dimensions of national innovation culture might help in modelling the national innovation system according to local context and in this way foster innovation more efficiently.

\section{NOTES}

1 The first research used four dimensions, the fifth dimension, long vs. short term orientation was added in 1988, and the latest dimension of indulgence vs. restraint was included in the 2010 survey (Hofstede et al., 2010). 
DRUŠ. ISTRAŽ. ZAGREB GOD. 20 (2011) BR. 4 (114)

STR. 1015-1038

LAŽNJAK, J.:

DIMENSIONS OF..
2 According to the Web of Science, in 2008 more than 800 peer-reviewed articles in scientific journals cited one or more of Geert Hofstede's publications.

${ }^{3}$ We would like to thank Dr. H. Hollanders (one of the authors of the EIS Report) who provided the data of Composite innovation index scores.

4 The project "Social Stratification and Values in Croatia" is financed by the Ministry of Science, Education and Sports, Republic of Croatia" (project leader Duško Sekulić).

\section{APPENDIX 1}

Correlation between Dimensions of National Culture and Composite Innovation Index (EU27+ Croatia, Iceland, FYR Macedonia, Norway, Switzerland and Turkey)

\begin{tabular}{|c|c|c|c|c|c|c|c|c|}
\hline & Spearman's rho & pdi & idv & mas & uai & ltowvs & ivr & CI \\
\hline \multirow[t]{3}{*}{ pdi } & Correlation Coefficient & 1.000 & $-0.563^{* *}$ & 0.092 & $0.696^{* *}$ & 0.117 & $-0.584^{* *}$ & $-0.666^{* *}$ \\
\hline & Sig. (2-tailed) & . & 0.001 & 0.629 & 0.000 & 0.539 & 0.001 & 0.000 \\
\hline & $\mathrm{N}$ & 30 & 30 & 30 & 30 & 30 & 30 & 30 \\
\hline \multirow[t]{3}{*}{ idv } & Correlation Coefficient & $-0.563^{* *}$ & 1.000 & 0.067 & $-0.536^{* *}$ & 0.131 & $0.408^{*}$ & $0.446^{*}$ \\
\hline & Sig. (2-tailed) & 0.001 & . & 0.725 & 0.002 & 0.491 & 0.025 & 0.014 \\
\hline & $\mathrm{N}$ & 30 & 30 & 30 & 30 & 30 & 30 & 30 \\
\hline \multirow[t]{3}{*}{ mas } & Correlation Coefficient & 0.092 & 0.067 & 1.000 & 0.150 & 0.162 & -0.015 & -0.005 \\
\hline & Sig. (2-tailed) & 0.629 & 0.725 & . & 0.428 & 0.393 & 0.935 & 0.978 \\
\hline & $\mathrm{N}$ & 30 & 30 & 30 & 30 & 30 & 30 & 30 \\
\hline \multirow[t]{3}{*}{ uai } & Correlation Coefficient & $0.696^{* *}$ & $-0.536^{* *}$ & 0.150 & 1.000 & -0.103 & -0.346 & $-0.442^{*}$ \\
\hline & Sig. (2-tailed) & 0.000 & 0.002 & 0.428 & . & 0.589 & 0.061 & 0.015 \\
\hline & $\mathrm{N}$ & 30 & 30 & 30 & 30 & 30 & 30 & 30 \\
\hline \multirow[t]{3}{*}{ ltowvs } & Correlation Coefficient & 0.117 & 0.131 & 0.162 & -0.103 & 1.000 & $-0.399 *$ & -0.026 \\
\hline & Sig. (2-tailed) & 0.539 & 0.491 & 0.393 & 0.589 & . & 0.024 & 0.886 \\
\hline & $\mathrm{N}$ & 30 & 30 & 30 & 30 & 32 & 32 & 32 \\
\hline \multirow[t]{3}{*}{ ivr } & Correlation Coefficient & $-0.584^{* *}$ & $0.408^{*}$ & -0.015 & -0.346 & $-0.399^{*}$ & 1.000 & $0.722^{* *}$ \\
\hline & Sig. (2-tailed) & 0.001 & 0.025 & 0.935 & 0.061 & 0.024 & . & 0.000 \\
\hline & $\mathrm{N}$ & 30 & 30 & 30 & 30 & 32 & 33 & 33 \\
\hline \multirow[t]{3}{*}{$\mathrm{CI}$} & Correlation Coefficient & $-0.666^{* *}$ & $0.446^{*}$ & -0.005 & $-0.442^{*}$ & -0.026 & $0.722^{* *}$ & 1.000 \\
\hline & Sig. (2-tailed) & 0.000 & 0.014 & 0.978 & 0.015 & 0.886 & 0.000 & . \\
\hline & $\mathrm{N}$ & 30 & 30 & 30 & 30 & 32 & 33 & 33 \\
\hline
\end{tabular}

** Correlation is significant at the 0.01 level (2-tailed)

${ }^{*}$ Correlation is significant at the 0.05 level (2-tailed)

Source: Innovation performance EIS, 2009; Six dimensions of national culture, Hofstede web page: http://www.geerthofstede.nl/research--vsm/dimension-data-matrix.aspx (downloaded 24.06.10) 
Factor Solution for National Culture Dimensions

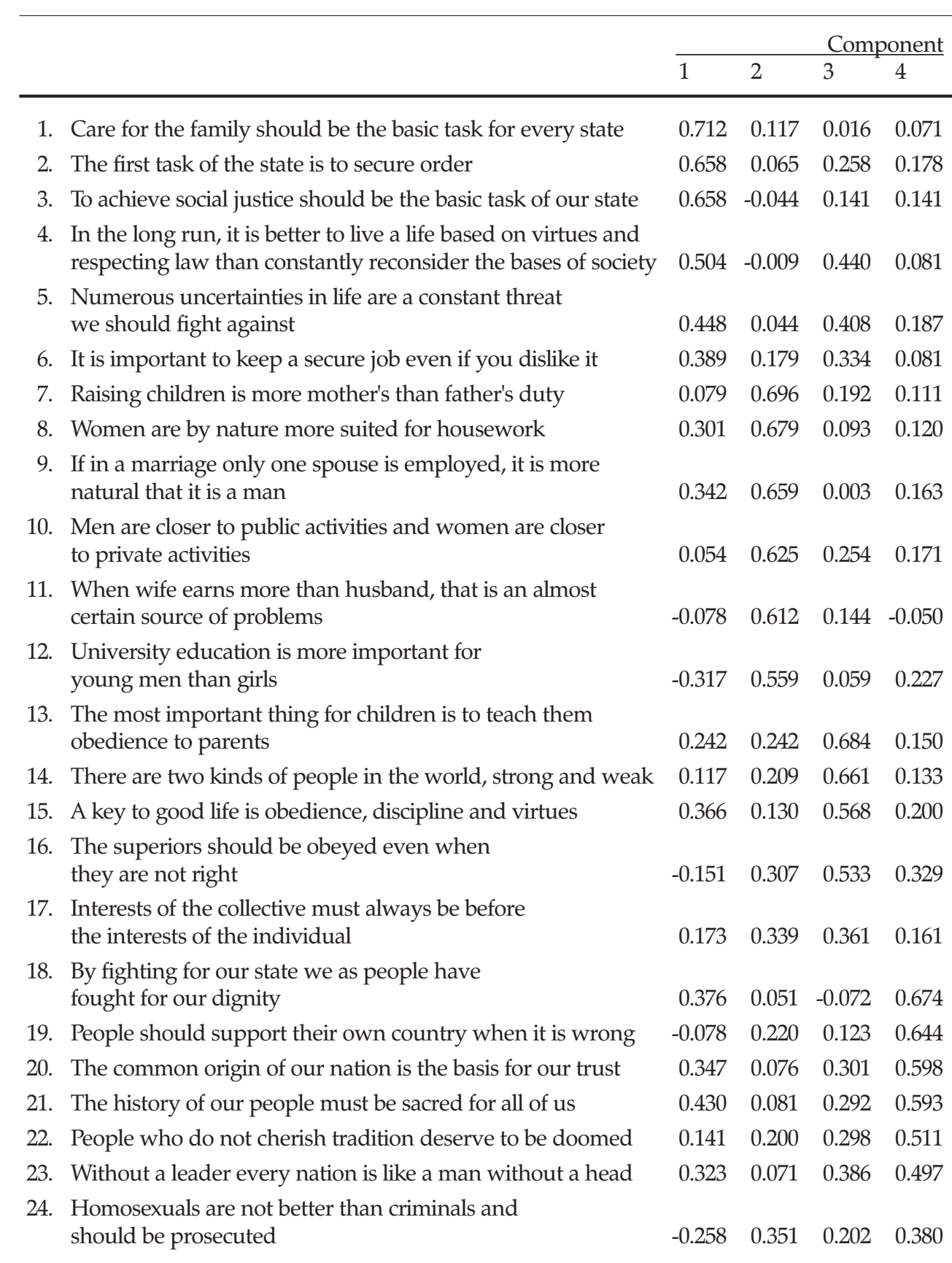

Extraction Method: Principal Component Analysis. Rotation Method: Varimax with Kaiser Normalization. Rotation converged in 8 iterations. Total variance explained: $49.06 \%$. 
Ahmed, K. P. (1998), Culture and Climate for Innovation. European Journal of Innovation Management, 1 (1): 30-43.

Babbie, E. (2008), The Basics of Social Research, Thomson Wadsworth.

Bijker, W. E., Hughes, T. P. and Pinch, T. (Eds.) (1989), The Social Construction of Technological systems, Cambridge, Ma, London, MIT Press.

Didero, M., Gareis, K., Marques, P., Ratzke, M. et al. (2008), Differences in Innovation Culture across Europe, Discussion paper, TRANSFORM project report, URL: http://www.transformeu.org/publications/documents/ Differences in Innovation Culture.pdf (retrieved 10. 7. 2008)

European Innovation Scoreboard 2008. Comparative Analysis of Innovation Performance (2009), Pro Inno Europe paper No 10, http://www. proinno-europe.eu/publications (retrieved, June 2010)

European Innovation Scoreboard Report (EIS) 2009 (2010), http://www. proinno-europe.eu/page/european-innovation-scoreboard-2009 (retrieved, 23. 9. 2011)

Franke, R. H., Hofstede, G. and Bond, M. H. (1991), Cultural Roots of Economic Performance: A Research Note. Strategic Management Journal, 12 (S1): 165-173. doi:10.1002/smj.4250120912

Freeman, C. (2002), Continental, National and Sub-National Innovation Systems - Complementary and Economic Growth. Research Policy, 31 (2): 191-211. doi:10.1016/S0048-7333(01)00136-6

Furman, J. L., Porter, M. E. and Stern, S. (2002), The Determinants of National Innovative Capacity. Research Policy, 31 (6): 899-933. doi:10.1016/ S0048-7333(01)00152-4

Geertz, C. (1973), The Interpretation of Cultures, New York, Basic Books.

Global Innovation Index (2011), http://www.globalinnovationindex.org/ gii/main/analysis/ (accessed Jan. 2011)

Hasan, I. and Tucci, C. L. (2010), The Innovation-Economic Growth Nexus: Global Evidence. Research Policy, 39 (10): 1264-1276. doi:10.1016/ j.respol.2010.07.005

Herbig, P. (1994), The Innovation Matrix: Culture and Structure Prerequisites to Innovation, Westport, Conn., Quorum Books.

Herbig, P. and Dunphy, S. (1998), Culture and Innovation. Cross Cultural Management: An International Journal, 5 (4): 13-21.

Hofstede, G. (1994), Cultures and Organizations. Software of the Mind, London, Harper Collins.

Hofstede, G. (2001), Culture's Consequences - Comparing Values, Behaviours, Institutions and Organizations across Nations, London, Sage Publications.

Hofstede, G., Hofstede, G. J. and Minkov, M. (2010), Cultures and Organizations: Software of the Mind. Revised and Expanded 3rd Edition, New York, McGraw-Hill.

Hofstede, G. (2010), Dimensionalizing Cultures; The Hofstede Model in Context, http://www.geerthofstede.nl/culture/dimensions-of-nationalcultures.aspx (accessed July 2010) 
DRUŠ. ISTRAŽ. ZAGREB GOD. 20 (2011), BR. 4 (114) STR. 1015-1038

LAŽNJAK, J.: DIMENSIONS OF..
Jucevičius, G. (2007), Innovation Culture: The Contestable Universality of the Concept. Social Sciences / Socialiniai Mokslai, 4 (58): 7-19.

Kaasa, A. and Vadi, M. (2008), How Does Culture Contribute to Innovation? Evidences from European Countries, Tartu, Tartu University Press, Available at: http://www.mtk.ut.ee/orb.aw/class=file/action= preview/id=423461/febawb63.pdf (downloaded March 2011)

Khazanchi, S., Lewis, W. M. and Boyer, K. K. (2007), InnovationSupportive Culture: The Impact of Organizational Values on Process Innovation. Journal of Operations Management, 25 (4): 871-884. doi:10. 1016/j.jom.2006.08.003

Kirkman, B. L., Lowe, K. B. and Gibson, C. B. (2006), A Quarter Century of Culture's Consequences: A Review of Empirical Research Incorporating Hofstede's Cultural Values Framework. Journal of International Business Studies, 37 (3): 285-320. doi:10.1057/palgrave. jibs.8400202

Kluckhohn, C. (1951), The Concept of Culture. In: D. Lerner and H. D. Lasswell (Eds.), The Policy Sciences, Stanford University Press, Stanford (according to Haralambos, M. and Holborn, M. (2002), Sociologija, Golden marketing, Zagreb (in Croatian).

Lundvall, B. A. (2007), National Innovation System: Analytical Focusing Device and Policy Learning Tool, Working paper, R2007-004, Swedish Institute for Growth Policy Studies, Östersund, Sweden.

MacKenzie, D. and Wajcman, J. (Eds.) (1999), The Social Shaping of Technology, Second Edition, Buckingham, Open University Press.

McSweeney, B. (2002), Hofstede's Model of National Cultural Differences and their Consequences: A Triumph of Faith - a Failure of Analysis. Human Relations, 55 (1): 89-118. doi:10.1177/0018726702551004

Minkov, M. and Blagoev, V. (2009), Cultural Values Predict Subsequent Economic Growth. International Journal of Cross Cultural Management, 9 (1): 5-24. doi:10.1177/1470595808101153

Moore, D. and Vamvakidis, A. (2007), Economic Growth in Croatia: Potential and Constraints, IMF Working paper WP/07/198, International Monetary Fund; http://www.imf.org/external/pubs/ft/wp/2007/wp07198. pdf (downloaded 20. 10. 2010)

Mytelka, L. K. and Smith, K. (2002), Policy Learning and Innovation Theory: An Interactive and Co-Evolving Process. Research Policy, 31 (8-9): 1467-1479. doi:10.1016/S0048-7333(02)00076-8

OECD (1992), Technology and Economy. The Key Relationships (TEP Report), OECD, Paris.

OECD (1997), The Oslo Manual: Proposed Guidelines for Collecting and Interpreting Technological Innovation Data, Paris, OECD.

Pavitt, K. (1998), The Social Shaping of the National Science Base. Research Policy, 27 (8): 793-805. doi:10.1016/S0048-7333(98)00091-2

Rammert, W. (2002), The Cultural Shaping of Technologies and the Politics of Technodiversity. In: K. H. Sorensen and R. Williams (Eds.), Shaping Technology, Guiding Policy. Concepts, Spaces, and Tools (pp. 173-194), Edward Elgar. 
DRUŠ. ISTRAŽ. ZAGREB GOD. 20 (2011) BR. 4 (114),

STR. 1015-1038

LAŽNJAK, J.: DIMENSIONS OF..
Schein, E. H. (1984), Coming to a New Awareness of Organizational Culture. MIT Sloan Management Review, 25 (2): 3-16.

Schumpeter, J. (1934), The Theory of Economic Development, Boston, Harvard University Press.

Shane, S. (1993), Cultural Influences on National Rates of Innovation. Journal of Business Venturing, 8 (1): 59-73. doi:10.1016/0883-9026(93) 90011-S

Sušanj, Z. (2000), Innovative Climate and Culture in Manufacturing Organizations: Differences between Some European Countries. Social Science Information, 39 (2): 349-391.

Švarc, J. (2008), Može li Hrvatska u društvo znanja i kako? (Can Croatia Enter Knowledge Society and How? In Croatian), Zagreb, Školska knjiga. Švarc, J., Lažnjak, J. and Šporer, Ž. (2009), Social Capital and Innovation Policy in Croatia: Scientific Community as a Source of Innovation. In: G. Tripp, M. Payne and D. Diodorus (Eds.), Social Capital (pp. 15-48), Nova Science Publishers Inc, New York.

Švarc, J., Lažnjak, J. and Perković, J. (2011), Unintended Consequences of the Innovation Policy Programmes: Social Evaluation of the Technological Projects Programme in Croatia. Innovation: Management, Policy \& Practice, 13 (1): 77-94.

Taras, V., Rowney, J. and Steel, P. (2009), Half a Century of Measuring Culture: Review of Approaches, Challenges, and Limitations Based on the Analysis of 121 Instruments for Quantifying Culture. Journal of International Management, 15 (4): 357-373. doi:10.1016/j.intman.2008. 08.005

Van Everdingen, Y. M. and Waarts, E. (2003), The Effect of National Culture on the Adoption of Innovations. Marketing Letters, 14 (3): 217-232. doi:10.1023/A:1027452919403

Vecchi, A. and Brennan, L. (2009), A Cultural Perspective on Innovation in International Manufacturing. Research in International Business and Finance, 23 (2): 181-192. doi:10.1016/j.ribaf.2008.03.008

Veugelers, R. and Mrak, M. (2009), The Knowledge Economy and Catching-up Member States of the European Union, Report prepared for Commissioner's Potocnik's Expert Group, "Knowledge for Growth" May 2009; http://ec.europa.eu/invest-in-research/pdf/download_en/ kfg_report_no5.pdf (retrieved 28.10. 2011)

Wieland, T. (2006), Innovation Culture, Technology Policy and Uses of History, URL: http://www.innovationskultur.mwn.de/papers/wieland_3. pdf (retrieved March 2011)

Willems, M. J. T. (2007), The Influence of Social Capital and Cultural Dimensions of Innovation, Master's Thesis, Universiteit Maastricht http://arno.unimaas.nl/show.cgi?fid =11419 (accessed January 2011)

Williams, L. K. and McGuire, S. J. J. (2005), Effects of National Culture on Economic Creativity and Innovation Implementation. The Institution of Market Exchange 2005. Conference proceedings, Barcelona, International Society for the New Institutional Economics.

Williamson, D. (2002), Forward from a Critique of Hofstede's Model of National Culture. Human Relations, 55 (11): 1373-1395. doi:10.1177/001 87267025511006

Županov, J. (1995), Poslije potopa (After the Flood, in Croatian), Zagreb, Globus. 
DRUŠ. ISTRAŽ. ZAGREB GOD. 20 (2011), BR. 4 (114), STR. 1015-1038

LAŽNJAK, J.: DIMENSIONS OF...

\section{Dimenzije nacionalne inovacijske kulture u Hrvatskoj. Sadržajna valjanost Hofstedeovih dimenzija}

Jasminka LAŽNJAK

Filozofski fakultet, Zagreb

Suočena s izazovom rasta inovacije u znanosti i tehnologiii, mnoga su društva razvila nacionalne inovacijske sustave kao oblik programa javne politike koji će poticati inovacije. Ako je inovacijska kultura ključna za usvajanje i razvoj novih tehnologija, vrlo je važno istražiti koncept i po mogućnosti saznati koji je tip kulture pogodniji za inovacije. U tekstu su prikazani rezultati prve empirijske studije inovacijske kulture dobiveni anketnim istraživanjem na reprezentativnom uzorku stanovništva Hrvatske. Oslanjajući se na Hofstedeov koncept dimenzija nacionalne kulture, hrvatska nacionalna inovacijska kultura operacionalizirana je kao skup vrijednosnih orijentacija i normi (izbjegavanje nesigurnosti, individualizam, maskulinitet/feminitet, dugoročna/kratkoročna orijentacija i distanca moći). Na temelju Hofstedeovih dimenzija, istraživanjem su konstruirane četiri skale koje uglavnom podupiru valjanost sadržaja njegova koncepta. Dobivene skale mogu se rabiti za mjerenje razlika $u$ inovativnom kapacitetu među raznim skupinama i regijama. Analiza pokazuje prisutnost mnogostrukih dimenzija inovacijske kulture u Hrvatskoj koje bi mogle ograničavati inovacijski kapacitet, ali to nikako ne znači da možemo identificirati samo jedan tip elemenata kulture koji osnažuje inovacijsku kulturu.

Ključne riječi: nacionalna inovacijska kultura, dimenzije nacionalne kulture, Hofstede, Hrvatska

\section{Dimensionen der nationalen Innovationskultur in Kroatien. Die inhaltliche Gültigkeit der Theorie von Hofstede}

Jasminka LAŽNJAK

Philosophische Fakultät, Zagreb

Angesichts der stets wachsenden Zahl von Innovationen in Wissenschaft und Technologie wurden in vielen Gesellschaften nationale Innovationssysteme entwickelt, die im Sinne öffentlicher politischer Programme die Entwicklung von Innovationen anregen sollen. Geht man davon aus, dass eine solche Innovationskultur die Einführung und Entwicklung never Technologien wesentlich mitbestimmt, ist es 
DRUŠ. ISTRAŽ. ZAGREB GOD. 20 (2011), BR. 4 (114)

STR. 1015-1038

LAŽNJAK, J.:

DIMENSIONS OF.. unerlässlich, dieses Konzept zu vertiefen und zu ermitteln, welcher Typ von Innovationskultur sich jeweils am besten eignet. Der vorliegende Artikel stellt die Ergebnisse der ersten empirischen Studie zur Innovationskultur dar, die in einer Umfrage unter repräsentativen Teilnehmern in Kroatien gewonnen wurden. In Anlehnung an Hofstedes Konzept der Dimensionen nationaler Kultur wird die nationale Innovationskultur Kroatiens operationalisiert und als Ansammlung wertmäßiger Orientierungen und Normen behandelt (Vermeiden von Unsicherheit, Individualismus, Maskulinität/Femininität, lang- und kurzfristige Orientierung sowie Distanz zur Macht). Auf der Grundlage der

Dimensionen nach Hofstede entwickelte die Autorin und Forscherin vier Skalen (Umfragebogen), die im Großen und Ganzen die inhaltliche Gültigkeit der Konzeption Hofstedes stüzzen. Die Skalen können zur Ermittlung von Unterschieden zwischen unterschiedlichen Innovationskapazitäten innerhalb verschiedener Bevölkerungsgruppen und Regionen eingesetz† werden. Die Analyse ergab, dass in Kroatien vielfältige Dimensionen von Innovationskultur gegenwärtig sind, durch die das bestehende Innovationsvermögen eingeengt werden könnte, doch bedeutet dies keineswegs, dass es nur einen Typus von Kulturelementen gebe, der die Innovationskultur stärkt.

Schlüsselbegriffe: Nationale Innovationskultur, Dimensionen nationaler Kultur, Hofstede, Kroatien 